\title{
Evaluation and characterization of triticale silage ( $x$. Triticosecale wittmack) to replace Sorghum bicolor (L.) Moench (S. vulgare Pers.) silage as feed for beef cattle
}

\section{Avaliação e caracterização de silagem de triticale ( $x$. Triticosecale wittmack) em substituição à silagem de sorgo (L.) Moench $(S$. vulgare Pers.) para alimentação de bovinos de corte}

\author{
Éderson Luis Henz ${ }^{1 *}$; Leandro das Dores Ferreira da Silva ${ }^{2}$; \\ Valter Harry Bumbieris Junior²; Fernando Luiz Massaro Junior ${ }^{1}$; \\ Ediane Zanin ${ }^{1}$; Maria Carolina Gonçalves de Arruda ${ }^{3}$
}

\section{Highlights:}

Sorghum silage presented lower amount of non-fibrous carbohydrates.

Triticale silage increased protein levels of high availability and rapid degradation in the rumen.

Non-fibrous carbohydrates presented degradation rates with positive linear effect.

\begin{abstract}
The objective of this study was to evaluate the nutritional quality of silages containing $0,25,50$, 75 and $100 \%$ triticale replacing sorghum silage feed for beef cattle. It was carried out fractionation of carbohydrates and proteins, and the parameters of ruminal degradation kinetics estimated by semiautomatic in vitro method of cumulative gas production of the silages. The experimental design completely randomized with five treatments and four replicates. Sorghum silage has less non-fibrous carbohydrates, and its substitution may explain the linear increase in the composition of fractions $\mathrm{A}$ and B1. In general, the proportions of fractions "A" and "B1 + B2" demonstrated that as sorghum replaced by triticale, the abundance of high availability proteins increased, as did the abundance of rapidly degradable proteins in the rumen. The final volume of gases produced by the fermentation of non-fibrous carbohydrates presented a negative linear relationship with increased triticale silage $(\mathrm{P}=$ $0.0001)$, while the degradation rates presented a positive linear relationship $(\mathrm{P}=0.0001)$. Thus, there was rapid release of energy and nitrogen, which may meet the needs of microorganisms. Therefore, triticale silage can be substituted for sorghum silage in cattle feed as an excellent source of protein and energy without altering nutritional parameters.
\end{abstract}

Key words: Food assessment. Gas production. Rate of degradation. Ruminant.

1 Discentes, Pós-Graduação em Ciência Animal, Universidade Estadual de Londrina, UEL, PR, Brasil. E-mail: ederhenz@gmail. com; massaro@uel.br; ediane.z@hotmail.com

2 Profs. Drs., Departamento de Zootecnia, UEL, PR, Brasil. E-mail: leandro@uel.br; jrbumbieris@uel.br

3 Discente, Pós-Graduação em Zootecnia, Universidade Estadual Paulista Júlio Mesquista Filho, UNESP, Jaboticabal, SP, Brasil. E-mail: mariacarolina281@gmail.com

* Author for correspondence 


\section{Resumo}

Objetivou-se avaliar a qualidade nutricional da silagem de triticale contendo $0 ; 25 ; 50 ; 75$ e $100 \%$ em substituição à silagem de sorgo. Foi realizado o fracionamento dos carboidratos em $\mathrm{A}+\mathrm{B} 1, \mathrm{~B} 2 \mathrm{e} \mathrm{C}$, e as proteínas em A, B1+B2, B3 e C das silagens. Os parâmetros de cinética de degradação ruminal foram estimados a partir do método semiautomático de produção cumulativa de gases in vitro e o inóculo ruminal foi obtido de bovinos adultos fistulados no rúmen, mantidos em pastagem de acordo com as normas de bem-estar animal. O delineamento experimental foi inteiramente casualizado com cinco tratamentos e quatro repetições e os dados foram submetidos à análise de variância e análise de regressão a 5\% de significância. A silagem de sorgo contém menor teor de carboidratos não fibrosos e maiores teores de proteínas das frações da fração A e B1. Ao se avaliar de maneira geral as proporções de frações "A" e "B1+B2" demonstraram que conforme o sorgo era substituído por triticale aumentava as proteínas de alta disponibilidade, bem como proteínas rapidamente degradáveis no rúmen. $\mathrm{O}$ volume final de gases produzidos pela fermentação dos carboidratos não fibrosos apresentou efeito linear negativo $(\mathrm{P}=0,0001)$ e as taxas de degradação apresentaram crescimento linear positivo $(\mathrm{P}=0,0001)$. Assim, houve rápida liberação de energia e nitrogênio, o que pode satisfazer as necessidades dos microrganismos. Portanto, a silagem de triticale pode substituir a silagem de sorgo para bovinos, sem prejuízo nos parâmetros nutricionais vindo a contribuir como uma ótima fonte de proteína e energia.

Palavras-chave: Avaliação de alimentos. Produção de gases. Taxa de degradação. Ruminantes.

\section{Introduction}

The adequacy of nutrients supplied in feed is an essential factor for animal performance. Feed should contain a satisfactory concentration of proteins and nonfibrous carbohydrates (starch and soluble sugars), the latter being the most important source of energy produced in the rumen. This concentration stimulates the growth of bacteria and increases the production of microbial protein and volatile fatty acids necessary to induce the milk or meat response (Henz et al., 2016).

Knowing the carbohydrate and protein content of feed is of the utmost importance in obtaining reliable estimates of its degradability in the rumen. Whether these nutrients come from protein-rich, energy-rich or voluminous foods, their ratios are fundamental in the formulation of balanced rations (Bumbieris et al., 2007).

The degradation of feed in the rumen is a complex process involving interactions between microorganisms and their host (Czerkawski, 1986). Although the in situ methodology of feed evaluation has been widely used (Orskov, Hovell, \& Mould, 1980), the surgical intervention for cannula implantation in animals has recently been the subject of ethical and moral discussions; many researchers have sought to replace it with in vitro techniques, such as those using methodologies that measure gas production (Velho et al., 2014).

The technique of measuring gas production is simple and inexpensive, making it widely accessible for evaluating feed for ruminants. It has the advantage of allowing for large numbers of samples to be processed in a short time, as well as providing gravimetric and metabolic data. There may be limitations in its usefulness; however, since standard protocols with 48-, 72- and 96-hour incubation times may impair the interpretation of the effects from experimental treatments on the most digestible parts of the feed (Velho et al., 2014).

When food is incubated with rumen fluid, the degraded fraction can be fermented to produce gases and acids or be incorporated into the microbial biomass (Pereira et al., 2013). Different foods may have the same magnitude but different rates of degradation; thus, there may be an increase in the flow of the particles out of the rumen, thus allowing for greater food intake (Ørskov, 1998).

In Brazil of subtropical and temperate climates, winter grain silages are an interesting alternative 
for the production of silage (Bumbieris et al., 2011), especially in situations where summer crops cannot be grown. Winter forages, such as wheat and triticale, are an interesting alternative for producing good quality preserved grains with significant dry matter and do not compete with summer grain production for land use. Therefore, the objective of this study was to evaluate triticale silage as a substitute for sorghum silage through in vitro ruminal degradation kinetics by the cumulative gas production technique.

\section{Materials and Methods}

This experiment was carried out at the Laboratory of Food Analysis and Animal Nutrition (LANA) of the Department of Animal Science of the State University of Londrina - Paraná, Brazil, between February 2015 and April 2016. This study was approved by the Ethics and Animal Use Committee (CEUA) under $\mathrm{N}^{\circ}$ 208/2014, process $\mathrm{N}^{\circ}$ 25227.2014.68. The planting of the cultivars was carried out on the school farm of the State University (FAZESC-UEL) located in Londrina, Paraná (2320'10" south latitude and $51^{\circ} 09^{\prime} 15^{\prime \prime}$ west longitude, $610 \mathrm{~m}$ high). The triticale (Triticosecale cv. IPR 111) and sorghum (Sorghum bicolor L., cv. Volumax) were used to make the silages. The cut occurred triticale crop with $40 \%$ DM and 28\% DM for the sorghum crop. Triticale silage was made in September 2015 and sorghum silage in the January 2016 with $22.5 \mathrm{~mm}$ particle size. For the preparation of both silages the enzymebacterial inoculant Lactosilo ${ }^{\circledR}$ was used, according to the manufacturer's recommendations, in order to provide the same fermentation conditions. The inoculant consists of L. curvatus, L. acidophilus, $L$. plantarum, L. Buchineri, P. acidilactici, E. faecium, L. lactic in the concentration of $10^{9} \mathrm{CFU} / \mathrm{g}$ each, Celulase $(85 \mathrm{u} / \mathrm{g})$.

The ensiled mass was compacted manually stored in mini silos of polyvinyl chloride $50 \mathrm{~cm}$ high and $10 \mathrm{~cm}$ in diameter with a stocking capacity of 550 $\mathrm{kg} / \mathrm{m}^{3}$ each and opening of both silos occurred 45 days after ensiling. To better evaluate the nutritive value of triticale silage, the beef cattle feed used in this study contained the levels $0,25,50,75$ or $100 \%$ triticale silage substituted for sorghum which were assessed base DM (Table 1).

Table 1

Chemical composition of triticale silages in substitution of sorghum silage in beef cattle feed expressed in base of DM

\begin{tabular}{lccccc}
\hline \multirow{2}{*}{ Parameter } & \multicolumn{5}{c}{ Levels of triticale silage } \\
\cline { 2 - 5 } & 0 & 25 & 50 & 75 & 100 \\
\hline Dry Matter (\% NM) & 47 & 46.5 & 46 & 45.25 & 45 \\
Mineral Matter & 5.15 & 5.60 & 5.60 & 6.00 & 6.10 \\
Extract Ether & 2.30 & 2.40 & 2.40 & 2.50 & 2.60 \\
Total Carbohydrates & 87.20 & 85.80 & 84.50 & 83.00 & 81.57 \\
Non-fibrous carbohydrates & 25.2 & 28.0 & 29.30 & 31.80 & 32.90 \\
Starch & 16.60 & 15.50 & 14.40 & 13.70 & 13.30 \\
NFDcp & 61.95 & 57.70 & 55.20 & 51.20 & 48.65 \\
AFD & 39.55 & 37.70 & 36.40 & 34.20 & 32.20 \\
Lignin & 5.50 & 4.80 & 4.40 & 3.90 & 3.6 \\
Crude Protein & 5.30 & 6.20 & 7.50 & 8.50 & 9.70 \\
Neutral Detergent Insoluble Protein & 1.40 & 1.30 & 1.20 & 1.13 & 1.10 \\
Acid Detergent Insoluble Protein & 1.20 & 1.10 & 1.05 & 1.00 & 0.90 \\
Total digestible nutrients & 61.60 & 63.7 & 65.00 & 66.2 & 68.1 \\
\hline
\end{tabular}

$\%$ NM, Natural matter; NFDcp, Neutral detergent fiber corrected for ash and protein; AFDcp, Corrected acid detergent fiber for ash and protein. 
Dry matter (DM), mineral matter (MM), crude protein $(\mathrm{CP})$ and ethereal extract (EE) were determined according to the methodologies described by Association of Official Analytical Chemists [AOAC] (1990). Neutral detergent fiber (NDF), acid detergent fiber (ADF), acid detergent lignin (ADL) obtained by means of acid digestion $\left(72 \% \mathrm{H}_{2} \mathrm{SO}_{4}\right.$, neutral detergent insoluble protein (NDIP), acid detergent insoluble protein (ADIP), and neutral detergent fiber corrected for ash and protein (NDFcp) were determined according to methods described by (Detmann et al., 2012). The fractionation and the calculation of carbohydrates were determined according to Sniffen, O'Connor, Van Soest, Fox and Russell (1992). The total digestible nitrogen (TDN) of the ingredients and feed was calculated according to Weiss, Conrad and Pierre (1992).

Fraction "A", or nonprotein nitrogenous compounds (NPN) $(\% \mathrm{CP})$, was calculated as the difference between the $\mathrm{N}$-total content and the $\mathrm{N}$-insoluble content in the Trichloroacetic acid (TCA). Fraction B1 + B2 was calculated by the formula $\mathrm{B} 1+\mathrm{B} 2(\% \mathrm{CP})=\%$ TCA - \% NDIP. Fraction $\mathrm{B} 3(\% \mathrm{CP})$ was calculated as the difference between the neutral detergent insoluble protein (NDIP) and the acid detergent insoluble protein (ADIP); fraction $\mathrm{C}$ was considered as acid detergent insoluble protein (ADIP), both fraction B3 and C were described by Sniffen et al. (1992).

The in vitro ruminal degradation kinetic parameters of the diets were estimated from the semiautomatic method of cumulative gas production described by Pell and Schofield (1993) and adapted to the conditions of the Animal Nutrition Laboratory of the State University of Londrina. The ruminal inoculum was obtained from rumen-fistulated adult cattle kept in pasture.

The buffer solution described by McDougall (1948) was prepared and heated to $39{ }^{\circ} \mathrm{C}$ under continuous $\mathrm{CO}_{2}$ gasification. Each incubation flask received $0.3 \mathrm{~g}$ of feed sample, $28.125 \mathrm{ml}$ of culture medium and $3.125 \mathrm{ml}$ of ruminal inoculum. Control flasks containing incubating solutions without substrate were incubated to account for variation. The vials were hermetically sealed using rubber stoppers.

The pressure of the accumulated gases produced by the fermentation of the substrate in the bottles was measured by means of a pressure gauge (after initial depressurization) at times 1, 2, 3, 4, 5, 6, 9, $12,18,24,30,36,48,60,72,84,96$ and 144 hours. The pressure values were converted to volume $(\mathrm{ml})$ according to the equation established for the local conditions: $\hat{Y}=0.5702+3.2399 \mathrm{P}+0.1074 \mathrm{P} 2(\mathrm{R} 2$ $=0.99$ ), where $\hat{\mathrm{Y}}=$ total volume of gas and " $\mathrm{P}$ " is the gas pressure inside the fermentation flasks (psi $=$ pressure per square inch), corrected for dry basis.

Kinetic parameters of ruminal fermentation were estimated from the data using the bicompartmental logistic model proposed by Schofield, Pitt and Pell (1994), described below: V (t) $=$ Vnfc / (1 $+\exp (2-4 * \mathrm{KdNFC} *(\mathrm{TL})))+\mathrm{VFC} /(1+\exp$ $(2-4 * \mathrm{KdFC} *$, where $\mathrm{Vnfc}=$ maximum volume of gases of the nonfibrous carbohydrate fraction (ml); VFC = maximum volume of gases of the fibrous carbohydrate fraction $(\mathrm{ml}) ; \mathrm{KdNFC}=$ rate of degradation of nonfibrous carbohydrates ( $\%$ h- 1 ); $\mathrm{KdFC}=$ rate of degradation of fibrous carbohydrates (\% h-1); and $\mathrm{T}$ and $\mathrm{L}=$ incubation time (hours) and latency (hours), respectively.

Estimates of the aforementioned fermentation kinetic parameters were generated using the nonlinear model procedure (PROC NLIN) within the (Statistical Analysis System [SAS], 2000). The fractions of total carbohydrates and crude protein were analyzed in a completely randomized design with 5 levels and 4 repetitions. The PROC GLM and PROC REG statistical packages in SAS (2000) were used to conduct analysis of variance tests and regression analyses on the data at a 5\% significance level. 


\section{Results and Discussion}

As triticale silage levels increased, the total carbohydrate content decreased, but the non-fibrous carbohydrates increased (Table 1). Fractions A and $\mathrm{B} 1$ (Table 2) differed $(\mathrm{P}=0.0001)$ among treatments. Fractions A and B1 are composed of soluble sugars, starch, pectin and glucan (Sniffen et al., 1992), which represent rapid ruminal degradation; these fractions are different among the treatments, presenting a positive relationship with increased triticale silage substitution. In temperate cereals such as triticale and barley, carbon stocks are accumulated in the stalk in the form of water-soluble carbohydrates, mainly fructose (Ruuska et al., 2008). Sorghum silage when compared to triticale silage, has less non-fibrous carbohydrates, and its replacement with triticale may explain the linear increase in the proportion of fractions $\mathrm{A}$ and $\mathrm{B} 1$.

\section{Table 2}

Fractionation of total carbohydrates of triticale silage in replacement of sorghum silage in beef cattle (\% DM)

\begin{tabular}{|c|c|c|c|c|c|c|}
\hline \multirow{2}{*}{ Parameter } & \multirow{2}{*}{ Statistic } & \multicolumn{5}{|c|}{ Triticale contents } \\
\hline & & 0 & 25 & 50 & 75 & 100 \\
\hline \multirow{2}{*}{ A } & Average & 31.35 & 35.90 & 38.90 & 43.1 & 46.5 \\
\hline & Regression & $\hat{\mathrm{Y}}_{\mathrm{A}}=3$ & $155^{*} \mathrm{x}$ & $\mathrm{P}=0.00$ & & \\
\hline \multirow{2}{*}{ B1 } & Average & 6.25 & 6.60 & 6.55 & 6.85 & 7.15 \\
\hline & Regression & $\hat{Y}_{B 1}=$ & $00867^{*}$ & $7 ; \mathrm{P}=0$ & & \\
\hline B2 & $\begin{array}{l}\text { Average } \\
\text { Regression }\end{array}$ & $\begin{array}{l}53.00 \\
\hat{Y}_{p 2}=\end{array}$ & $\begin{array}{l}49.75 \\
.120 * x\end{array}$ & $\begin{array}{l}47.60 \\
\mathrm{P}=0.00\end{array}$ & 44.15 & 41.30 \\
\hline C & $\begin{array}{l}\text { Average } \\
\text { Regression }\end{array}$ & $\begin{array}{l}9.35 \\
\hat{Y}_{C}=9 .\end{array}$ & $\begin{array}{r}7.80 \\
31 * x\end{array}$ & $\begin{array}{c}6.90 \\
\mathrm{P}=0.000\end{array}$ & 5.85 & 5.15 \\
\hline
\end{tabular}

Values expressed as mean $\pm \mathrm{SE}$. A+B1, Non-fibrous carbohydrates (\% TCHO); B2, Available components corresponding to the potentially degradable fraction $(\% \mathrm{TCHO})$; $\mathrm{C}$, Indigestible fraction of the cell wall $(\% \mathrm{TCHO})$.

According to Tylutki et al. (2008), non-fibrous carbohydrate-fermenting ruminal bacteria use starch, pectin and sugars, and they grow faster than fibrous carbohydrate fermenters since they can use ammonia or amino acids as a nitrogen source. Therefore, silages such as triticale that stimulate the growth of ruminal bacteria capable of fermenting non-fibrous carbohydrates increase the production of microbial protein and volatile fatty acids, favoring the ruminant response and resulting in a performance while also stimulating the production of propionate, which reduces methane generation (Van Soest, 1994).

The $\mathrm{B} 2$ fraction also differed $(\mathrm{P}=0.0001)$ among treatments, decreasing as sorghum silage replaced that of triticale (Table 2). The B2 fraction decreased as sorghum silage replaced that of triticale. The decreasing content of NDFCP (Table 1) contributed to the decrease of the fibrous carbohydrates, as this fraction is composed of the fibrous carbohydrates of the cell wall, which have slow ruminal degradability and are susceptible to passage rate effects (Sniffen et al., 1992).

The $\mathrm{C}$ fraction of carbohydrates also differed $(\mathrm{P}=$ $0.0001)$ as sorghum silage was replaced by triticale silage (Table 2). The $\mathrm{C}$ fraction of the carbohydrates as sorghum silage was replaced by triticale silage. This fraction represents the unavailable lignified cell wall that causes indigestibility of structural carbohydrates (Van Soest, 1994), and its variation can be explained by the higher lignin content of sorghum compared to triticale.

With regard to nitrogen compounds, there was an increase $(\mathrm{P}=0.0001)$ in fraction $\mathrm{A}$ (non-protein nitrogen - NPN) compounds with increasing triticale silage, and the $\mathrm{C}$ fraction differed $(\mathrm{P}=0.0001)$ 
among treatments as well (Table 3). The observed increase in the proportion of fraction A may be due to the protein content of triticale silage being higher than that of sorghum silage. The proportions of fractions "A" and "B1 + B2" (Table 3) demonstrated that as sorghum was replaced by triticale, the amount of high availability proteins increased in the rumen, as did the amount of rapidly degradable proteins. However, Nocek and Russell (1988) stated that when the availability of rapidly degradable proteins is high, it is necessary to adjust the carbohydrate supply with rapid degradation, so that there is a synchronism between the fermentation of carbohydrates and that of the proteins present in the rumen. This adjustment exerts an important effect on the final product of ruminal fermentation and, consequently, on the performance and production of the animals.

Table 3

Fractionation of proteins, expressed as total crude protein (\% CP) of triticale silage in replacement of sorghum silage in beef cattle (\% DM)

\begin{tabular}{|c|c|c|c|c|c|}
\hline \multirow{2}{*}{ Parameter } & \multirow{2}{*}{ Statistic } & \multicolumn{4}{|c|}{ Triticale contents } \\
\hline & & 25 & 50 & 75 & 100 \\
\hline \multirow{2}{*}{ A } & Average & 44.65 & 49.75 & 54.20 & 54.85 \\
\hline & Regression & $\hat{\mathrm{Y}}_{\mathrm{A}}=39.076+0.0182 *_{\mathrm{X}}$ & $\left(\mathrm{r}^{2}=80 ; \mathrm{P}=0.0001\right)$ & & \\
\hline \multirow{2}{*}{ B1 +B2 } & Average & $\begin{array}{ll}\text { A } & 33.45\end{array}$ & 33.85 & 32.50 & 33.60 \\
\hline & Regression & $\hat{\mathrm{Y}}_{\mathrm{B} 1+\mathrm{B} 2}=33.90$ & & & \\
\hline \multirow{2}{*}{ B3 } & Average & $3.75 \quad 3.40$ & 2.05 & 1.80 & 2.20 \\
\hline & Regression & $\hat{\mathrm{Y}}_{\mathrm{B} 3}=3.596-0.0187 * \mathrm{x}$ & $\left(\mathrm{r}^{2}=24 ; \mathrm{P}=0.0164\right)$ & & \\
\hline \multirow{2}{*}{$\mathrm{C}$} & Average & $23.30 \quad 18.10$ & 14.30 & 11.5 & 9.30 \\
\hline & Regression & $\hat{Y}_{C}=22.336-0.142 * x$ & $\left.\mathrm{r}^{2}=96 ; \mathrm{P}=0.0001\right)$ & & \\
\hline
\end{tabular}

Values expressed as mean $\pm \mathrm{SE}$. A, non-protein nitrogen; B1+B2, degradable protein; B3, slowly degradable protein; C, protein unavailable.

The protein content considered as the $\mathrm{B} 3$ fraction decreased as triticale content increased, which guarantees good quality of triticale silage compared to sorghum and shows that the availability of protein is greater in triticale silage than sorghum. One of the reasons for a greater $\mathrm{C}$ fraction in sorghum than triticale is because sorghum does not develop protection for seeds such as the glumes of triticale and barley. The sorghum plant does, however, produce several phenolic compounds, which serve as a chemical defense against birds, pathogens and other competitors.

According to Sniffen etal. (1992), the unavailable protein fraction is represented in fraction $C$. These proteins are insoluble in detergent acid (ADIP) and correspond to the proteins associated with lignin and products from the reaction of Maillard, which are highly resistant to microbial and indigestible enzymes present throughout the gastrointestinal treatment.

Evaluation of the kinetics parameters of in vitro ruminal fermentation (Table 4) verified that the final volume of gases produced by the fermentation of nonfibrous carbohydrates (Vnfc) was inversely related to the increase of triticale content in substitution of sorghum silage ( $\mathrm{P}=0.0001)$, while degradation rates (Kdnfc) had a positive linear relationship with increased triticale substitution ( $\mathrm{P}$ $=0.0001)$.

The final volume of gases produced by the fermentation of nonfibrous carbohydrates (Vnfc) presented a negative linear trend as triticale content increased in replacement of sorghum silage. The degradation rates $(\mathrm{Kdnfc})$ presented a positive linear relationship with increased triticale content. 
Thus, it can be affirmed that there was rapid release of energy and nitrogen, satisfying the needs of the microorganisms that use the highly degradable nonfibrous carbohydrates (NFC) in the rumen.

Table 4

Parameters of ruminal degradation of triticale silage in replacement of sorghum silage in beef cattle (\% DM)

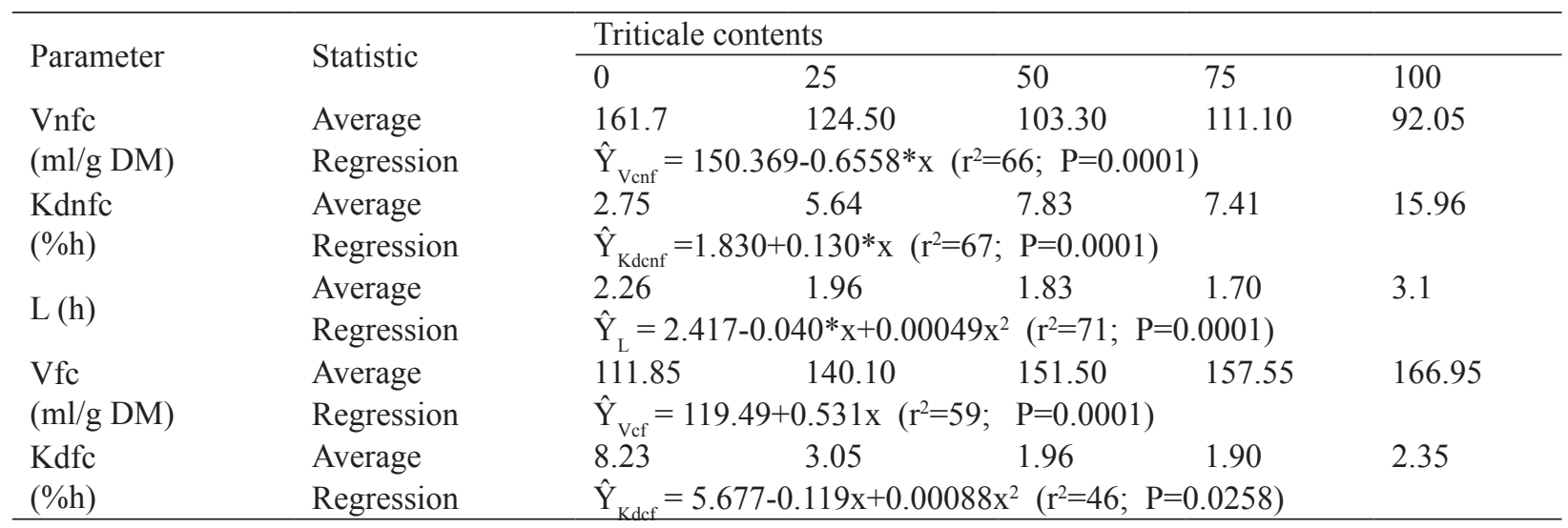

Values are expressed as mean \pm SE. Final volume of production of fibrous carbohydrate gases (Vcfc) and non-fibrous (Vnfc) in $\mathrm{ml} / \mathrm{g}$ DM; Rate of degradation of fibrous carbohydrates (KdFC) and non-fibrous (KdNFC) in \%/h; Latency (L) in an hour.

Decreased levels of NDFcp and lignin influenced the colonization time $(\mathrm{P}=0.0001)$ in this experiment. The time of colonization is an important parameter related to the degradation of the fibrous fraction of the food (Velho et al., 2014) because a longer lag time indicates that the diet negatively affected the colonization time of the ruminal microorganisms.

Decreases in the levels of NDFc and lignin influenced colonization time in this experiment $(\mathrm{P}=0.0001)$. It was verified that the final volume of gases produced by the fermentation of fibrous carbohydrates (Vfc) presented a linear relationship with increased sorghum replacement by triticale $(\mathrm{P}$ $=0.0001)$, and the degradation rates $(\mathrm{Kdfc})$ were negatively influenced by sorghum replacement $(\mathrm{P}=$ 0.0001).

The final volume of gases produced by the fermentation of fibrous carbohydrates (Vfc) increased as sorghum was replaced by triticale $(P=0.0001)$, and the change in silage negatively influenced $(\mathrm{P}=0.0001)$ degradation rates $(\mathrm{Kdfc})$. This effect can be attributed to the decrease in total carbohydrate content and reduction in lignin content, allowing for an increase in the A + B1 (carbohydrate) fraction values. As the proportion of triticale silage increased to substitute for sorghum, carbohydrates were more available for ruminal degradation.

According to Russell, O'Connor, Fox, Van Soest and Sniffen (1992), the presence of soluble nitrogen stimulates the structural carbohydrate-fermenting ruminal microorganisms to use ammonia as a source of nitrogen, thus improving the degradation of the structural carbohydrates of the ration. This increase in carbohydrate degradation was observed in the present study.

\section{Conclusions}

The substitution of triticale sorghum silage in the beef cattle ration influenced carbohydrate, protein and ruminal degradation parameters. Therefore, triticale silage can substitute sorghum silage for cattle without compromising on nutritional and metabolic parameters, contributing as an excellent voluminous source of complete rations for beef cattle. 


\section{Acknowledgments}

The authors would like to thank the postgraduate program in Animal Science of the State University of Londrina (UEL, Londrina, Brazil) and this study was financed in part by the Coordenação de Aperfeiçoamento de Pessoal de Nível Superior Brasil (CAPES) - Finance Code 001.

\section{References}

Association of Official Analytical Chemists. (1990). Official methods of analysis (15th ed.). Arlington: AOAC Internacional.

Bumbieris, V. H., Jr., Dias, F. J., Kazama, R., Arruda, D. S. R. de, Jobim. C. C., \& Morais, M. da G. (2007). Ruminal degradability and carbohydrate fractioning of stargrass silages (Cynodon nlemfuensis vanderyst.) with different additives. Semina: Ciências Agrárias, 28(4),761-772. doi: 10.5433/1679-0359.2007v28n4p761

Bumbieris, V. H., Jr., Jobim, C. C., Emile, J. C., Rossi, R., Calixto, M., Branco, A. F. (2011). Ruminal degradability and carbohydrates and proteins fractioning of triticale silages in singular culture or in mixtures with oat and/or legumes. Semina: Ciências Agrárias, 32(2), 759-70. doi:10.5433/1679$0359.2011 \mathrm{v} 32 \mathrm{n} 2 \mathrm{p} 759$

Czerkawski, J. (1986, Sep). Degradation of solid feeds in the rumen: spatial distribution of microbial activity and its consequences. In Control of Digestion and Metabolism in Ruminants. Proceedings of the Sixth International Symposium on Ruminant Physiology, Banff, Canada, pp. 158-172.

Detmann, E., Valadares, S. de C., F., Queiroz, A. C., Berchielli, T. T., Saliba, E. O. S., Cabral, L. S., Azevedo, J. A. (2012). Métodos para análise de alimentos. Visconde do Rio Branco: Suprema Gráfica e Editora; Viçosa: Universidade Federal de Viçosa.

Henz, É. L., Almeida, P. S. G. de, Velho, J. P., Nörnberg, J. L., Silva, L. D. D. F. da, Backes, T. R., \& Guerra, G. L. (2016). Dual purpose wheat production with different levels of nitrogen topdressing. Semina: Ciências Agrárias, 37(2), 1091-1100. doi: 10.5433/1679-0359.2016v37n2p1091

McDougall, E. (1948). Studies on ruminant saliva. The composition and output of sheep's saliva. Biochemical Journal, 43(1), 99-109. doi: 10.1042/ bj0430099
Nocek, J. E., \& Russell, J. B. (1988). Protein and energy as an integrated system. relationship of ruminal protein and carbohydrate availability to microbial synthesis and milk production. Journal of Dairy Science, 71(8), 2070-2107. doi: 10.3168/jds.S00220302(88)79782-9

Ørskov, E. (1998). Feed evaluation with emphasis on fibrous roughages and fluctuating supply of nutrients: a review. Small Ruminant Research, 28(1), 1-8. doi: 10.1016/S0921-4488(97)00042-4

Orskov, E., Hovell, F. D. B., \& Mould, F. (1980). The use of the nylon bag technique for the evaluation of feedstuffs. Tropical Animal Production, 5(3), 195213.

Pell, A., \& Schofield, P. (1993). Computerized monitoring of gas production to measure forage digestion in vitro. Journal of dairy Science, 76(4), 1063-1073. doi:10.3168/jds.S0022-0302(93)77435-4

Pereira, E. S., Mizubuti, I. Y., Ribeiro, L. E. de A., Neiva, J. N. M., Pimentel, P. G., Duarte, L. S., Rocha, J. N., Jr. (2013). Estimativa do valor nutricional de subprodutos agroindustriais pelo uso da técnica de produção de gás. Semina: Ciências Agrárias, 34(1), 391-398. doi: 10.5433/1679-0359.2013v34n1p391

Russell, J. B., O'Connor, J. D., Fox, D. G., Van Soest, P. J., \& Sniffen, C. J. (1992). A net carbohydrate and protein system for evaluating cattle diets: I. Ruminal fermentation. Journal of Animal Science, 70(11), 3551-3561. doi: 10.2527/1992.70113551x

Ruuska, S. A., Lewis, D. C., Kennedy, G., Furbank, R. T., Jenkins, C. L. \& Tabe, L. M. (2008). Large scale transcriptome analysis of the effects of nitrogen nutrition on accumulation of stem carbohydrate reserves in reproductive stage wheat. Plant Molecular Biology, 66(1-2), 15-32. doi: 10.1007/ s11103-007-9249-5

Statistical Analysis System Institute. (2000). SAS/STAT User's Guide: Statistics, Version 6, 27 th Ed. Cary: SAS Institute Inc, N.C.

Schofield, P., Pitt, R., \& Pell, A. (1994). Kinetics of fiber digestion from in vitro gas production. Journal of Animal Science, 72(11), 2980-2991. doi: 10.2527/1994.72112980x

Sniffen, C. J., O'Connor, J. D., Van Soest, P. J., Fox, D. G., \& Russell, J. B. (1992). Anet carbohydrate and protein system for evaluating cattle diets: II. Carbohydrate and protein availability. Journal of Animal Science, 70(11), 3562-3577. doi:10.2527/1992.70113562x 
Tylutki, T., Fox, D., Durbal, V., Tedeschi, L., Russell, J., Van Amburgh, M., Pell, A. (2008). Cornell Net Carbohydrate and Protein System: A model for precision feeding of dairy cattle. Animal Feed Science and Technology, 143(1-4), 174-202. doi: 10.1016/j.anifeedsci.2007.05.010

Van Soest, P. J. (1994). Nutritional ecology of the ruminant. Ithaca: Cornell University Press.
Velho, J. P., Mühlbach, P. R. F., Genro, T. C. M., Barcellos, J. O. J., Braccini, J., Neto, \& Silva, R. S. M. da. (2014). Modelos matemáticos para ajuste da produção de gases in vitro em diferentes tempos de incubação e cinética ruminal de silagens de milho. Semina: Ciências Agrárias, 35(4), 2531-2540. doi: 10.5433/1679-0359.2014v35n4Supl1p2531

Weiss, W., Conrad, H., \& Pierre, N. (1992). Atheoreticallybased model for predicting total digestible nutrient values of forages and concentrates. Animal Feed Science and Technology, 39(1-2), 95-110. doi: 10.1016/0377-8401(92)90034-4 
